\title{
Chromium-induced Inhibition of Insulin Secretion from Isolated Islets of Langerhans
}

\author{
T. Ghafghazi, M. L. McDaniel, and P. E. Lacy \\ Department of Pathology, Washington University School of Medicine, St. Louis, Missouri, USA
}

\begin{abstract}
Summary. $\mathrm{CrCl}_{3}, 0.25,0.5,1.0$, and $1.5 \mathrm{mmol} / 1$ inhibited glucose-induced insulin secretion in a reversible and dose dependent manner. $\mathrm{Cr}$ also inhibited basal secretion of insulin in the presence of $5.5 \mathrm{mmol} / \mathrm{l}$ glucose and insulin secretion stimulated by $50 \mathrm{mmol} / 1 \mathrm{~K}^{+}$or $15 \mathrm{mmol} / \mathrm{l}$ L-leucine. When $2 \mathrm{mmol} / 1$ theophylline was employed to potentiate the stimulatory effect of $16.5 \mathrm{mmol} / \mathrm{l}$ glucose, the inhibitory effect of $1.5 \mathrm{mmol} / \mathrm{l} \mathrm{Cr}$ was reduced and that of $0.5 \mathrm{mmol} / 1 \mathrm{Cr}$ virtually abolished. A similar reduction in the inhibitory effect of $\mathrm{Cr}$ was observed when the medium calcium concentration was increased from 2.5 to $5,7.5$ and $12.5 \mathrm{mmol} / 1$. $\mathrm{Cr}$ did not alter the conversion of ${ }^{14} \mathrm{C}$-glucose to ${ }^{14} \mathrm{CO}_{2}$ or ${ }^{45} \mathrm{Ca}$ uptake by isolated islets. It is concluded that the inhibitory effect of $\mathrm{Cr}$ on insulin secretion may be mediated through interference with an intracellular function of $\mathrm{Ca}^{++}$in the beta cell.
\end{abstract}

Key words: Insulin secretion, chromium, isolated rat islet, calcium interaction with chromium.

Chromium has been recognized as a trace element essential for both animal and human nutrition. It plays a role in the maintenance of normal glucose tolerance in at least some species of animals [1]. Rats fed a diet deficient in $\mathrm{Cr}$ developed impaired glucose tolerance, hyperglycaemia, and glycosuria [2]. Levine et al. [3] reported that $\mathrm{Cr}$ supplementation improved glucose tolerance in some elderly diabetic patients, but Sherman et al. [4] found in a younger diabetic population that prolonged $\mathrm{Cr}$ feeding failed to improve the glucose tolerance. Moreover, Cr treatment worsened the already existing hyperglycaemia in some diabetic patients [5]. Also, in experimental animals receiving a normally constituted diet, the administration of $\mathrm{Cr}$ was reported to increase plasma glucose levels $[6,7]$.

The biological effects of $\mathrm{Cr}$ on carbohydrate homeostasis, and its current clinical application in diabetes emphasizes the significance of defining the role of $\mathrm{Cr}$ in these processes. The purpose of the present study was to assess the effect of $\mathrm{Cr}$ on insulin secretion and to determine the mechanisms by which this trace element affects the secretory response of isolated pancreatic islets.

\section{Materials and Methods}

Isolated pancreatic islets were obtained by collagenase digestion [8] from adult (200-300 g) male Wistar rats allowed food and water ad libitum. All incubations were performed in a modified Krebs-Ringer bicarbonate medium (KRB) containing mmol/l: 115 $\mathrm{NaCl}, 5.0 \mathrm{KCl}, 2.5 \mathrm{CaCl}_{2}, 24 \mathrm{NaHCO}_{3}, 1.0 \mathrm{MgCl}_{2}$ and $0.5 \%(\mathrm{w} / \mathrm{v})$ bovine plasma albumin, Armour Pharmaceutical Co., Chicago, IL. The medium was equilibrated to $\mathrm{pH} 7.4$ with a humidified mixture of $\mathrm{O}_{2}(95 \%)$ and $\mathrm{CO}_{2}(5 \%)$ and maintained at $37^{\circ} \mathrm{C}$.

D-glucose was obtained from the National Bureau of Standards, Washington, D. C.; L-Leucine from Sigma Chemical Co., St. Louis; Sucrose, $\mathrm{KCl}, \mathrm{CrCl}_{3}$, and toluene from Fisher Scientific Co., and theophylline from $\mathrm{K}+\mathrm{K}$ Laboratories, Plainview, NJ; D$\left[\mathrm{U}_{-}{ }^{14} \mathrm{C}\right]$ glucose, $\left[{ }^{3} \mathrm{H}\right]$ sucrose, and ${ }^{45} \mathrm{CaCl}_{2}$ from New England $\mathrm{Nu}-$ clear Corp., Boston, MA.; Hydroxide of Hyamine-10X, PPO, and POPOP were obtained from Packard Instrument Co.

Chromium inhibition of insulin release was determined in a static incubation system. After isolation, pancreatic islets were transferred with the aid of a Pasteur pipette and dissection microscope to roundbottomed vials ( $11 \mathrm{~mm}$ diameter $\times 20 \mathrm{~mm}$ height) which contained $200 \mu \mathrm{l}$ of KRB medium. Each vial contained 25 islets and $12-15$ vials were employed per experiment. The glass incubation vials were inserted into scintillation vials equipped with rubber stoppers, gassed with $\mathrm{O}_{2} / \mathrm{CO}_{2}(95 \% / 5 \%)$ and shaken in a Dubnoff Metabolic Shaker $(70-100$ cycles $/ \mathrm{min})$. The islets were then preincubated for $30 \mathrm{~min}$ in $200 \mu \mathrm{l}$ of glucose-free medium containing different concentrations of $\mathrm{CrCl}_{3}(0.25,0.50,1.0$, and $1.5 \mathrm{mmol} / \mathrm{l})$. The preincubation medium was removed and replaced with $200 \mu \mathrm{l}$ of $\mathrm{D}$-glucose $(27.5 \mathrm{mmol} / \mathrm{l})$ medium for 
Table 1. Effect of $\mathrm{Cr}$ on glucose-induced insulin release

\begin{tabular}{|c|c|c|c|c|c|}
\hline & \multicolumn{2}{|c|}{$\begin{array}{l}\text { Ionic composition } \\
\text { of medium }\end{array}$} & \multicolumn{2}{|c|}{ Insulin release $\mu \mathrm{U} / \mathrm{min}$ per islet } & \multirow{2}{*}{$\begin{array}{l}\% \\
\text { inhibition }\end{array}$} \\
\hline & $\overline{\mathrm{Cr}^{+++}}$ & $\mathrm{Ca}^{++}$ & Control & Experimental & \\
\hline & & & Glucose $5.5 \mathrm{mmol} / \mathrm{l}$ & & \\
\hline 1 & 0.25 & 2.5 & $0.59 \pm 0.05(15)$ & $0.52 \pm 0.06(13)$ & 12 \\
\hline 2 & 0.50 & 2.5 & $0.53 \pm 0.07(8)$ & $0.42 \pm 0.04(8)$ & 25 \\
\hline 3 & 1.0 & 2.5 & $0.54 \pm 0.06(10)$ & $0.34 \pm 0.03(10)$ & 38 \\
\hline \multirow[t]{2}{*}{4} & 1.5 & 2.5 & $0.59 \pm 0.05(15)$ & $0.31 \pm 0.02(13)$ & 47 \\
\hline & & & Glucose $27.5 \mathrm{mmol}$ & & \\
\hline 5 & 0.25 & 2.5 & $2.46 \pm 0.12(15)$ & $2.06 \pm 0.09(15)$ & 16 \\
\hline 6 & 0.50 & 2.5 & $2.65 \pm 0.08(25)$ & $1.84 \pm 0.07(30)$ & 30 \\
\hline 7 & 1.0 & 2.5 & $2.49 \pm 0.11(21)$ & $1.62 \pm 0.06(26)$ & 37 \\
\hline 8 & 1.5 & 2.5 & $2.66 \pm 0.09(28)$ & $1.36 \pm 0.06(31)$ & 49 \\
\hline 9 & 0 & 5.0 & & $3.03 \pm 0.18(22)$ & \\
\hline 10 & 1.5 & 5.0 & & $1.86 \pm 0.09(24)$ & 3810 vs $8 \alpha 9 \mathrm{P}<0.05$ \\
\hline 11 & 0 & 7.5 & & $2.97 \pm 0.12(27)$ & \\
\hline 12 & 1.5 & 7.5 & & $2.04 \pm 0.09(28)$ & 3112 vs $8 \alpha 11 \mathrm{P}<0.05$ \\
\hline 13 & 0 & 12.5 & & $2.79 \pm 0.12(22)$ & \\
\hline 14 & 1.5 & 12.5 & & $1.82 \pm 0.08(24)$ & 3514 vs $8 \alpha 13 \mathrm{P}<0.05$ \\
\hline
\end{tabular}

After preincubation for $30 \mathrm{~min}$ in glucose-free $\mathrm{KRB}$ in the absence (control) or presence (experimental) of $\mathrm{Cr}$, the medium was removed from the islets and replaced with medium containing glucose $(5.5$ or $27.5 \mathrm{mmol} / \mathrm{l})$ and the indicated $\mathrm{Cr}$ concentration for a stimulation period of $30 \mathrm{~min}$. Values represent the mean \pm SEM with the number of observations in parenthesis. Statistical comparison with the corresponding control group showed significant differences $P<0.01-0.001$ ) in all cases except 0.25 and $0.50 \mathrm{~mm} / \mathrm{l}$ at $5.5 \mathrm{mmol} / 1 \mathrm{glucose}$. The significances of differences among the groups with increasing calcium concentration were also estimated by factorial analysis of variance and the Newman-Keuls test

Table 2. Reversal of $\mathrm{Cr}$ inhibition of glucose-induced insulin release

\begin{tabular}{lll}
\hline $\begin{array}{l}\text { Experimental } \\
\text { condition }\end{array}$ & \multicolumn{2}{l}{ Insulin release $(\mu \mathrm{U} / \mathrm{min}$ per islet $)$} \\
\cline { 2 - 3 } & $\begin{array}{l}\text { First stimulation } \\
\text { period }\end{array}$ & $\begin{array}{l}\text { Second stimulation } \\
\text { period }\end{array}$ \\
\hline Control & $2.64 \pm 0.10(13)$ & $3.27 \pm 0.17(13)$ \\
$\mathrm{Cr}(0.5 \mathrm{mmol} / \mathrm{l})$ & $1.72 \pm 0.09(15)$ & $3.12 \pm 0.13(15)$ \\
$\mathrm{Cr}(1.5 \mathrm{mmol} / \mathrm{l})$ & $1.35 \pm 0.09(15)$ & $3.20 \pm 0.18(15)$ \\
\hline
\end{tabular}

Experimental procedures for the first stimulation period were as in Table 1. For the second stimulation period the islets were rinsed once with KRB medium $(250 \mu \mathrm{l})$, and then incubated in KRB medium $(200 \mu \mathrm{l})$ containing $5.5 \mathrm{mmol} / 1$ glucose for $15 \mathrm{~min}$. This medium was then removed and replaced with incubation medium with $27.5 \mathrm{mmol} / \mathrm{l}$ glucose for a second stimulation period of $30 \mathrm{~min}$. Values represent mean $\pm \mathrm{SEM}$ with the number of observations in parenthesis

$30 \mathrm{~min}$ in the presence of $\mathrm{CrCl}_{3}$. Control groups were treated identically except in the absence of the test agent. At the end of the stimulation period the medium was removed and frozen for insulin assay by the method of Wright et al. [9] with crystalline porcine insulin as standard and ${ }^{125} \mathrm{I}$-labelled porcine insulin as tracer. None of the experimental agents studied interfered with the measurement of insulin by the radioimmunoassay.

\section{${ }^{45}$ Ca Uptake}

${ }^{45} \mathrm{Ca}$ uptake into isolated islets was measured with a doubleisotope procedure described previously [10]. Twenty-five islets were preincubated for $30 \mathrm{~min}$ at $37^{\circ} \mathrm{C}$ in $200 \mu \mathrm{l}$ of glucose-free medium in the presence of $1.5 \mathrm{mmol} / \mathrm{Cr}$ followed by incubation for $30 \mathrm{~min}$ in $200 \mu \mathrm{l} \mathrm{medium} \mathrm{containing} 1.5 \mathrm{mmol} / 1 \mathrm{Cr}, 2.5 \mathrm{mmol} / 1$ ${ }^{45} \mathrm{CaCl}_{2}(0.22 \mathrm{GBq} / \mathrm{mmol})$, and $5 \mathrm{mmol} / \mathrm{l}\left[{ }^{3} \mathrm{H}\right]$-sucrose $(0.25 \mathrm{GBq} /$ mmol) as the extracellular marker, and $27.5 \mathrm{mmol} / 1$ glucose. ${ }^{45} \mathrm{Ca}$ uptake into the islets of the control group was studied in the absence of $\mathrm{Cr}$.

\section{Glucose Oxidation}

Batches of 20-25 islets were preincubated for $30 \mathrm{~min}$ in glass incubation vials in glucose-free medium which contained $1.5 \mathrm{mmol} / \mathrm{l}$ Cr. At the end of the preincubation period, the medium was removed and $200 \mu \mathrm{l}$ of incubation medium containing $1.5 \mathrm{mmol} / 1$ $\mathrm{Cr}$ and uniformly labelled $16 \mathrm{mmol} / 1\left[{ }^{14} \mathrm{C}\right]$-D-glucose $(0.022 \mathrm{GBq}$ mmol) was added. The measurement of ${ }^{14} \mathrm{CO}_{2}$ production was performed over $2 \mathrm{~h}$ as described previously [11].

\section{Statistical Analysis}

Insulin release is expressed as $\mu \mathrm{U}$ insulin/min per islet. In these experiments, each observation is based on 25 individual islets. Statistical analysis was made by the two tailed Student " $t$ " test comparing the combined observations from separate experiments.

\section{Results}

\section{Effect of $\mathrm{Cr}$ on Insulin Release Induced by Glucose and Other Agents}

Table 1 summarizes the effect of $\mathrm{Cr}$ on glucoseinduced insulin secretion by isolated rat islets. Chromium, $\quad 0.25-1.5 \mathrm{mmol} / \mathrm{l}$, inhibited insulin release in a dose-dependent manner. Chromium, 1 and $1.5 \mathrm{mmol} / \mathrm{l}$, significantly reduced basal secretion 
Table 3. Effect of $1.5 \mathrm{mmol} / 1 \mathrm{Cr}$ on insulin secretion stimulated with $\mathrm{K}^{+}$or L-leucine

\begin{tabular}{|c|c|c|c|c|}
\hline $\begin{array}{l}\text { Experimental } \\
\text { condition }\end{array}$ & $\begin{array}{l}\text { Insulin release }(\mu \mathrm{\tau} \\
\text { Control }\end{array}$ & Experimental & $\begin{array}{l}\mathrm{P} \\
\text { value }\end{array}$ & $\begin{array}{l}\% \\
\text { inhibition }\end{array}$ \\
\hline $\begin{array}{l}\mathrm{K}^{+}(50 \mathrm{mmol} / \mathrm{l}) \\
\text { L-leucine }(15 \mathrm{mmol} / 1)\end{array}$ & $\begin{array}{l}2.87 \pm 0.12(16) \\
2.92 \pm 0.10(21)\end{array}$ & $\begin{array}{l}1.97 \pm 0.12(16) \\
1.88 \pm 0.09(21)\end{array}$ & $\begin{array}{l}<0.001 \\
<0.001\end{array}$ & $\begin{array}{l}31 \\
36\end{array}$ \\
\hline
\end{tabular}

After preincubation for $30 \mathrm{~min}$ in $\mathrm{KRB}$ medium containing $5.5 \mathrm{mmol} / \mathrm{l}$ glucose in the absence (control) and presence (experimental) of Cr, the medium was removed from the islets and replaced with medium containing $5.5 \mathrm{mmol} / 1$ glucose and $\mathrm{K}^{+}$or $\mathrm{L}$-leucine in the absence or presence of $\mathrm{Cr}$ for a stimulation period of $30 \mathrm{~min}$. Values represent mean $\pm \mathrm{SEM}$ with the number of observations in parenthesis

Table 4. Effect of $\mathrm{Cr}$ on insulin secretion stimulated with glucose and theophylline

\begin{tabular}{|c|c|c|c|c|c|}
\hline \multirow{2}{*}{$\begin{array}{l}\text { Experimental } \\
\text { condition }\end{array}$} & \multicolumn{5}{|c|}{ Insulin release $(\mu \mathrm{U} / \mathrm{min}$ per islet) } \\
\hline & Control & $0.5 \mathrm{mmol} / \mathrm{l} \mathrm{Cr}$ & $\%$ inhibition & $1.5 \mathrm{mmol} / 1 \mathrm{Cr}$ & $\%$ inhibition \\
\hline $\begin{array}{l}\text { Glucose, } 16.5 \mathrm{mmol} / 1 \\
\text { Glucose, } 16.5 \mathrm{mmol} / 1\end{array}$ & $3.37 \pm 0.30(10)$ & $2.12 \pm 0.06(10)$ & 37 & $1.74 \pm 0.12(10)$ & 49 \\
\hline $\begin{array}{c}+ \\
\text { Theophylline, } 2 \mathrm{mmol} / \mathrm{l}\end{array}$ & $4.95 \pm 0.27(15)$ & $4.37 \pm 0.29(15)$ & 12 & $3.32 \pm 0.19(15)$ & 33 \\
\hline
\end{tabular}

Experimental procedures were identical to Table 1. Statistical comparison with corresponding control group showed significant differences $(\mathrm{P}<0.005-0.001)$ in all cases except for $0.5 \mathrm{mmol} / 1 \mathrm{Cr}$ and glucose + theophylline. Values represent the mean $\pm \mathrm{SEM}$ with the number of observations in parenthesis

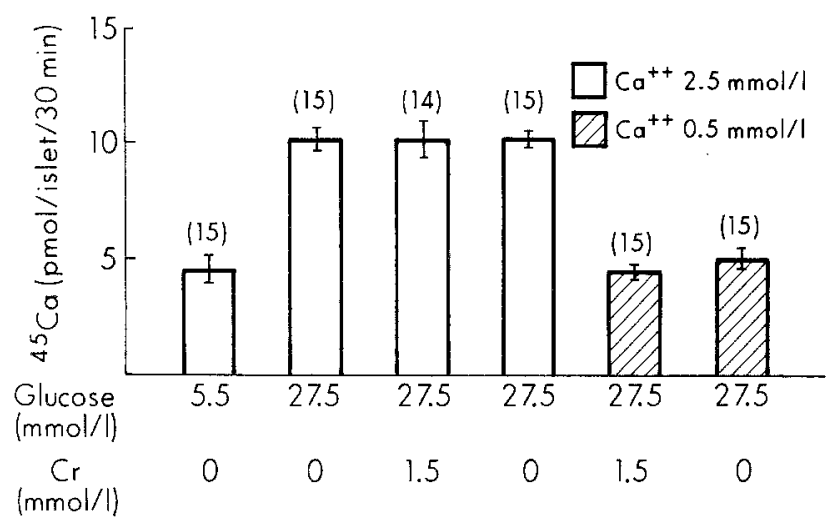

Fig. 1. Effect of glucose and $\mathrm{Cr}$ on ${ }^{45} \mathrm{Ca}$ uptake in isolated islets. Islets were preincubated for $30 \mathrm{~min}$ in $\mathrm{KRB}$ medium in the presence or absence of $1.5 \mathrm{mmol} / \mathrm{l} \mathrm{Cr} .{ }^{45} \mathrm{Ca}$ uptake of the islets was determined after incubation for $30 \mathrm{~min}$ in a medium containing ${ }^{45} \mathrm{Ca},\left[{ }^{3} \mathrm{H}\right]$ sucrose and either 5.5 or $27.5 \mathrm{mmol} / 1$ glucose in the presence or absence of $1.5 \mathrm{mmol} / 1 \mathrm{Cr}$. Calcium concentrations of medium were $2.5 \mathrm{mmol} / 1$ or $0.5 \mathrm{mmol} / \mathrm{l}$ as indicated. Values represent the mean \pm SEM with the number of observations in parenthesis

at $5.5 \mathrm{mmol} / 1 \mathrm{D}$-glucose. The inhibitory effect of $\mathrm{Cr}$ on glucose-induced insulin secretion was reversible (Table 2). Chromium, $1.5 \mathrm{mmol} / 1$, also inhibited insulin secretion induced by $50 \mathrm{mmol} / 1$ potassium or $15 \mathrm{mmol} / 1$ L-leucine (Table 3 ).

\section{Effect of $\mathrm{Cr}$ on Insulin Secretion}

Stimulated with Glucose and Theophylline

The addition of $2 \mathrm{mmol} / \mathrm{l}$ theophylline to medium containing (Table 4) $16.5 \mathrm{mmol} / \mathrm{l}$ glucose enhanced insulin release, compared with islets incubated without theophylline. In the presence of theophylline, the inhibitory effect of $1.5 \mathrm{mmol} / \mathrm{l} \mathrm{Cr}$ was reduced from $49 \%$ to $33 \%$. The inhibitory effect of $0.5 \mathrm{mmol} / \mathrm{l} \mathrm{Cr}$ was completely prevented by theophylline.

\section{Effects of Calcium on $\mathrm{Cr}$ Inhibition of Insulin Secretion}

Increasing the medium calcium concentration from 2.5 to $5.0,7.5$ and $12.5 \mathrm{mmol} / 1$ increased the secretion of insulin by islets, but this increase was not statistically significant (Table 1). However, the inhibitory effect of $\mathrm{Cr}$ was significantly diminished in the presence of higher calcium concentrations in the medium (Table 1, lines 10, 12 and 14 vs 8 ).

\section{Lack of $\mathrm{Cr}$ Effect on ${ }^{45} \mathrm{Ca}$ Uptake and $D$ - $\left[{ }^{14} C\right]$-Glucose Oxidation}

${ }^{45} \mathrm{Ca}$ uptake was measured in islets in the presence of 5.5 and $27.5 \mathrm{mmol} / 1$ glucose in KRB medium containing $2.5 \mathrm{mmol} / \mathrm{l}$ calcium (Fig. 1). Increasing the concentration of glucose from 5.5 to $27.5 \mathrm{mmol} / \mathrm{l}$ enhanced ${ }^{45} \mathrm{Ca}$ uptake 2 fold (Fig. 1). However, $1.5 \mathrm{mmol} / \mathrm{l} \mathrm{Cr}$ at a $\mathrm{Ca}^{++} / \mathrm{Cr}^{+++}$ratio of $1.67 \mathrm{did} \mathrm{not}$ alter glucose-induced ${ }^{45} \mathrm{Ca}$ uptake by isolated islets. When the calcium concentration in the KRB medium was reduced from 2.5 to $0.5 \mathrm{mmol} / 1,1.5 \mathrm{mmol} / 1 \mathrm{Cr}$ at the $\mathrm{Ca} / \mathrm{Cr}$ ratio of 0.33 also failed to modify glucoseinduced ${ }^{45} \mathrm{Ca}$ uptake. Chromium at $1.5 \mathrm{mmol} / \mathrm{l} \mathrm{did}$ not modify the rate of $\mathrm{D}-\left[{ }^{14} \mathrm{C}\right]$-glucose $(16.5 \mathrm{mmol} / \mathrm{l})$ oxidation by isolated islets: control condition, $85.5 \pm$ 
2.6 (15 observations) vs $\mathrm{Cr}$ treatment, $83.8 \pm$ $3.9 \mathrm{pmol} \mathrm{D}$-glucose oxidized $/ 2 \mathrm{~h}$ per islet.

\section{Discussion}

We have reported [7] that the acute administration of chromium to rats increases blood glucose levels and causes intolerance to a glucose load. This hyperglycaemic response to $\mathrm{Cr}$ is prompt in onset and lasts for only $5 \mathrm{~h}$ or less.

The present experiments were designed to evaluate the effect of $\mathrm{Cr}$ on insulin secretion from isolated rat islets and thus to elucidate the mechanism of Crinduced hyperglycaemia. The experiments show that $\mathrm{Cr}$ inhibits insulin release from islets stimulated with glucose, leucine, or potassium in a dose-dependent manner. $\mathrm{Cr}$ also inhibits basal insulin secretion in the presence of $5.5 \mathrm{mmol} / 1$ glucose (a non-stimulatory concentration). The inhibition of non-stimulated insulin secretion suggests the existence of mechanisms for regulating the basal release of hormone.

The inhibitory effect of $\mathrm{Cr}$ on glucose-induced insulin secretion is completely reversible by removal of $\mathrm{Cr}$ from the incubation medium. Theophylline also totally reverses the inhibitory effect produced by a low concentration of $\mathrm{Cr}(0.5 \mathrm{mmol} / 1)$, and partially reverses the effect of a higher dose of $\mathrm{Cr}(1.5 \mathrm{mmol} / 1)$. This antagonistic effect of theophylline suggests a possible mechanism for the inhibitory effect of $\mathrm{Cr}$ on insulin secretion. One proposed mechanism by which theophylline potentiates glucose-induced insulin release is by increasing islet cell levels of cAMP which then leads to an intracellular translocation of calcium [12]. Thus, in the present study there may have been an interaction between $\mathrm{Cr}$ and $\mathrm{Ca}$ which resulted in inhibition of insulin secretion. This hypothesis was tested by increasing the medium calcium concentration from 2.5 to $5.0,7.5$, and $12.5 \mathrm{mmol} / \mathrm{l}$. The higher calcium concentrations partially but significantly antagonized the inhibitory effect of $\mathrm{Cr}$ on insulin secretion.

The partial but significant antagonism of $\mathrm{Cr}-$ induced inhibition of insulin secretion by theophylline or increased calcium concentration, and the lack of an inhibitory effect of $\mathrm{Cr}$ on glucose metabolism and ${ }^{45} \mathrm{Ca}$ uptake support the hypothesis that $\mathrm{Cr}$ inhibits insulin release by an intracellular interaction with calcium. However, other mechanisms such as interaction with sulfhydryl groups of the plasma or granule membrane [13] cannot be ruled out.

The clinical use of $\mathrm{Cr}$ for improvement of glucose tolerance in diabetic patients is open to question in view of the effects in the rat, in which species $\mathrm{Cr}$ induces hyperglycaemia [7] as well as inhibition of insulin release from isolated islets. Although the continued administration (16-24 days) of $\mathrm{Cr}$ to rats failed to affect the response of animals to a glucose load [14], it has been reported that $\mathrm{Cr}$ treatment in some diabetic patients worsens the diabetes [5]. Therefore, $\mathrm{Cr}$ is not a drug for the general treatment of disturbances of carbohydrate metabolism. The apparent effect of supplementation with $\mathrm{Cr}$ can have useful practical importance only if $\mathrm{Cr}$ deficiency can be expected to exist in individual subjects.

Acknowledgements. The authors thank Mrs. C. G. Bry, Mrs. Joan Fink and Mr. R. W. Homer. The studies were supported by NIH grant AM-03373. Dr. Ghafghazi was a Fulbright Fellow.

\section{References}

1. Mertz W (1969) Chromium occurrence and function in biological systems. Physiol Rev 49: 163-239

2. Schroeder HA (1966) Chromium deficiency in rats: A syndrome simulating diabetes mellitus with retarded growth. J Nutr 88: 439-445

3. Levine RA, Streeten D JP, Doisy R J (1968) Effects of oral chromium supplementation on the glucose tolerance of elderly human subjects. Metabolism 17: 114-125

4. Sherman L, Glennon J A, Brech W J, Klomberg GH, Gordon ES (1968) Failure of trivalent chromium to improve hyperglycemia in diabetes mellitus. Metabolism 17: 439-442

5. Wise A (1978) Chromium supplementation and diabetes. JAMA 240: 2045-2046

6. Vakhrusheva VA (1960) Effect of manganese and chromium as trace elements on the level of blood sugar in white mice. $\mathrm{Tr}$ Izhevskogo Otd Vses Fisiol Obsh 1: 184-190

7. Ghafghazi T, Maghbareh A, Barnett R (in press) Chromiuminduced hyperglycemia in the rat. Toxicology

8. Lacy PE, Kostianovsky M (1967) Method for the isolation of intact islets of Langerhans from the rat pancreas. Diabetes 16: 35-39

9. Wright PH, Makulu DR, Vichick D, Sussman KE (1971) Insulin immunoassay by back-titration; some characteristics of the technic and the insulin precipitant action of alcohol. Diabetes 20 : $33-45$

10. Naber S P, McDaniel ML, Lacy PE (1977) The effect of glucose on the acute uptake and efflux of calcium -45 in isolated rat islets. Endocrinology 101: 686-693

11. McDaniel ML, King S, Anderson S, Fink J, Lacy PE (1974) Effect of cytochalasin $B$ on hexose transport and glucose metabolism in pancreatic islets. Diabetologia 10: 303-308

12. Brisson GR, Malaisse-Lagae F, Malaisse W J (1972) The stimulus-secretion coupling of glucose-induced insulin release. VII. A proposed site of action for adenosine- $-3^{\prime},-5^{\prime}$-cyclic monophosphate. J Clin Invest 51: 232-241

13. Watkins D T, Moore M (1974) Effect of sulfhydrylbinding reagents on insulin release from isolated secretion granules. Endocrinology 95: 485-491

14. Ghafghazi T, Maghbareh A, Barnett R (1978) Effect of chromium on glucose tolerance in the rat. I R C S Med Sci 6: 396

Received: June 12, 1979 ,

and in revised form: October 2, 1979

Michael L. McDaniel, Ph. D.

Department of Pathology

Washington University School of Medicine

660 S. Euclid Avenue

St. Louis, MO 63110

USA 